\title{
DOUBLE JEOPARDY: A NEW TRIAL AFTER APPELLATE REVERSAL FOR INSUFFICENT EVIDENCE
}

A federal jury finds a defendant innocent and judgment is rendered. Under generally accepted principles of double jeopardy the government may not bring a new action against him for the same crime. Another defendant is convicted of the same charge. On appeal his conviction is reversed for insufficient evidence, the appellate court deciding that the defendant should have been acquitted. One would expect that the same principles which protected the first defendant from further prosecution would apply equally to the second. Surprisingly, however, the Supreme Court has held that the principles which protect the first defendant do not protect the second. 1

This comment undertakes to examine critically the waiver theory by which the Court reached this conclusion and proposes a new approach for an analysis of the double jeopardy implications of a new trial after appellate reversal which avoids this anomaly.

The Supreme Court was first confronted by the question of the constitutionality of a remand for a new trial after a reversal for insufficient evidence in Bryan $v$. United States. ${ }^{2}$ The Court after extensive discussion found no statutory objection to a new trial. Then, in one short paragraph, Mr. Justice Minton rejected the contention that a new trial would place the defendant in double jeopardy. "He sought and obtained the reversal of his conviction, assigning a number of alleged errors on appeal, including denial of his motion for judgment of acquittal. ... [W] [Were the accused successfully seeks review of a conviction, there is no double jeopardy upon a new trial."3

The cursory treatment given the double jeopardy problem in the Bryan case reveals the Court's feeling that no new, significant double jeopardy question had been presented. The Court's quotation from Francis $v$. Resweber that "where the accused successfully seeks review of a conviction, there is no double jeopardy upon a new trial" 4 was dictum. Resweber relied on United States v. Ball. ${ }^{5}$ But there the reversal was for a defective indictment rather than insufficient evidence. Trono $v$. United

1 Bryan v. United States, 338 U.S. 552 (1950).

2 Ibid.

3338 U.S. at 560, quoting Francis v. Resweber, 329 U.S. 459, 462 (1947) and citing Trono v. United States, 199 U.S. 521, 533-34 (1905).

4329 U.S. 459,462 (1947).

5163 U.S. 662 (1895). 
States, ${ }^{6}$ cited by the Bryan court, also relied on the Ball case. Since the Supreme Court appears to have regarded Ball as controlling, the Court apparently felt that the double jeopardy question in the Bryan case was the same as if the new trial had followed a reversal due to error.

The rule of the Bryan case may have been significantly limited, however, in Sapir $v$. United States. ${ }^{\top}$ The court of appeals had first reversed and remanded the case with orders to discharge the defendant on grounds of insufficient evidence. Later, the court amended its judgment and granted a new trial because of newly discovered evidence. The Supreme Court avoided the double jeopardy question in a per curiam opinion reinstating the first judgment. The Court argued that since it felt that the first judgment was correct it was unnecessary to pass on questions presented by the judgment granting a new trial. ${ }^{8}$

Concurring in Sapir, Mr. Justice Douglas addressed himself to the constitutional question. He argued that a new trial after an acquittal by an appellate court for lack of evidence was no different from a new trial after an acquittal by a trial court, and that both were proscribed by the double jeopardy clause of the fifth amendment. Mr. Justice Douglas distinguished the Bryan case on the ground that there the defendant had asked for a new trial.

The extent to which Mr. Justice Douglas' concurring opinion in Sapir may be accepted is not clear. The question has been squarely presented in two lower federal courts. In both United States $v$. Reina, ${ }^{9}$ and Rucker $\boldsymbol{v}$. United States, ${ }^{10}$ a new trial was awarded after a reversal for insufficient evidence even though a new trial had not been requested. In the Rucker case the defendant had even expressly disclaimed any intention of waiving his double jeopardy protection. Neither case cited nor dealt with the effect of Sapir, both citing only Bryan.

In Forman v. United States, 11 however, the Supreme Court seemed to treat Douglas' opinion as law. The defendant had appealed his conviction seeking a new trial. The court of appeals first reversed his conviction and remanded for an acquittal due to an erroneous instruction by the trial court on the statute of limitations. The defendant had asked for a new trial on different grounds. On rehearing, the court of appeals amended

6199 U.S. 521 (1905).

7348 U.S. 373 (1955).

8 The Court's disposition of the case is in contrast to the usual rule which commits to the discretion of the court of appeals the appropriate disposition after reversal. See the interpretation of 28 U.S.C. $\$ 2106$ (1958) in Bryan v. United States, 338 U.S. 552, 554-58 (1950).

9172 F. Supp. 113 (S.D.N.Y. 1959).

10228 F.2d 146 (D.G. Cir. 1961).

11361 U.S. 416 (1960). 
its original order and remanded for a new trial. The Supreme Court held that a new trial would not invade the defendant's constitutional protection from double jeopardy. Treating Sapir as raising constitutional issues, the Court distinguished it on two grounds. First, the Sapir case had dealt with a new trial after reversal for insufficient evidence while in Forman the reversal had been for error. Second, "Sapir made no motion for a new trial in the District Court, while [in the Forman case] . . . petitioner filed such a motion. That was a decisive factor in Sapir's case."12

Thus, holdings in the federal courts indicate that a new trial following a reversal due to insufficient evidence will not infringe a defendant's double jeopardy protection if he has requested the new trial. It is unclear whether a new trial where the defendant has not requested it would violate the double jeopardy clause. The language in Forman recognizing Mr. Justice Douglas' dissent in Sapir suggests that the Court might hold that it would. But in Reina and Rucker the lower federal courts failed to consider the impact of Sapir and treated Bryan as stating the controlling law.

Cases which permit a new trial after reversal for error usually reason that the defendant waives his double jeopardy protection by appealing. ${ }^{13}$ The Supreme Court in Bryan apparently extended this waiver rationale to situations where an appellate court orders a new trial for insufficient evidence. If the waiver rationale is in fact the proper explanation for those cases which permit a new trial after reversal for error, its extension to a new trial after a reversal for insufficient evidence is logical. But it can be demonstrated that although the courts talk in terms of waiver, such a rationale is fictional and cannot be support for allowing a new trial in cases involving either error or insufficient evidence.

In Green v. United States ${ }^{14}$ the Supreme Court decided that the waiver

12 Id. at 426. (Emphasis added.) It is interesting to note that the Forman court was satisfied that a new trial had been asked for even though it was asked for on grounds different from those which were responsible for the reversal. This might suggest that if Mr. Justice Douglas' opinion in Sapir is accepted, and Bryan is restricted to cases where a new trial is requested, the standard will be satisfied if at any time in the proceedings and for any reason a new trial is asked for. Such a rule would attach undue significance to a request for a new trial. A request for a new trial should be considered consent to a second trial only if the new trial is granted for the reason it was requested. A defendant who appeals on grounds of error asking for a new trial and on grounds of insufficient evidence asking for reversal and acquittal has hardly consented to a new trial after reversal for insufficient evidence.

13 E.g., Trono v. United States, 199 U.S. 521, 533-34 (1905); United States v. Gonzales, 206 Fed. 239 (W.D. Wash. 1913); State v. Phillips, 175 Kan. 50, 259 P.2d 185 (1953). See generally Green v. United States, 355 U.S. 184, 189 (1957); Bishop, Crrminal LAw §§ 998-1003 (9th ed. 1923); Miller, Criminal LaW § 186(e) (1934); Comment, 24 MiNN. L. REV. 522, 534-35 (1940).

14355 U.S. 184 (1957). 
rationale could not justify allowing a new trial for murder after errors caused the reversal of a trial on a murder indictment where the jury found the defendant guilty only of manslaughter. The Court found that waiver must be a "voluntary knowing relinquishment of a right."15 When a defendant is forced to surrender his double jeopardy protection against a second trial for murder to get a review of his manslaughter conviction, his choice cannot be considered voluntary. But if the important issue is whether or not the defendant actually waived his constitutional guarantee, then it is hard to see how his choice in the Bryan situation is any more voluntary than it is in the Green situation. A choice between jail and second jeopardy hardly makes for a "voluntary knowing relinquishment of a right." In fact, "usually no such waiver is expressed or thought of." 16 The difficulty with Green, of course, is that if its requirement of a voluntary, knowing waiver is to be taken seriously, then a defendant could never be subjected to a new trial after an appellate reversal. After exposing the waiver fiction, the opinion fails to develop any alternative rationale for the American rule which generally permits a new trial after appellate reversal. But in spite of this crucial conceptual shortcoming the case may have laid the waiver rationale to rest once and for all.

Other grounds have been urged for allowing a new trial after a conviction has been reversed. One notion is that the new trial is really a continuation of the first and that since the jeopardy continues, the defendant has not been placed in a second jeopardy. ${ }_{17}$ But adherence to this theory would permit the prosecution to appeal from an acquittal, a result which has been rejected by the Supreme Court. ${ }^{18}$

Equally unacceptable is the notion that a reversal wipes out the previous jeopardy.19 The double jeopardy clause is meaningful only if every jeopardy counts. There would never be a second jeopardy if only the last counted. If the appellate court had not reversed the defendant would have been punished. He therefore was in jeopardy.

$15 I d$. at 191. It has also been held that where a constitutional right to counsel exists, a waiver must be intelligent and understanding. Carnley v. Cochran, 369 U.S. 506, 513 (1962).

16 Kepner v. United States, 195 U.S. 100, 135 (1904) (dissent of Mr. Justice Holmes), See also, dissent of Mr. Justice Frankfurter in Green v. United States, 355 U.S. 184, 219 (1957).

17 Mayers and Yarbrough, Bis Vexari: New Trials and Successive Prosecutions, 74 Harv. L. Rev. 6 (1960). See, e.g., United States v. Berry, 309 F.2d 311 (7th Cir. 1962); State v. Aus, 105 Mont. 82, 69 P.2d 584 (1937).

18 Kepner v. United States, 195 U.S. 100 (1904). See Mayers and Yarbrough, supra note 17, at 8-15, where the authors argue that the state should be allowed an appeal after an acquittal.

19 See, e.g., Bayless v. United States, 147 F.2d 169 (8th Cir. 1945); State v. Robinson, 100 Ohio App. 466, 137 N.E. 2d 141 (1956). 
Rather than resort to fictions, it would seem more fruitful to concede that a new trial after appellate reversal is second jeopardy and then attempt to articulate the considerations which have led the courts to permit the imposition of this second jeopardy on a defendant. This was Mr. Justice Frankfurter's approach in his dissent in Green $v$. United States:20

Undeniably the framers of the Bill of Rights were concerned to protect defendants from oppression and from efforts to secure, through the callousness of repeated prosecutions, convictions for whose justice no man could vouch. On the other hand, they were also aware of the countervailing interest in the vindication of criminal justice, which sets outer limits to the protections for those accused of crimes. Thus if a defendant appeals his conviction and obtains a reversal, all agree, certainly in this country, that he may be retried for the same offense. ${ }^{21}$

In Wade v. Hunter, ${ }^{22}$ the Supreme Court considered the problem of when the double jeopardy clause forbids a second trial where the original jury trial had been discontinued without a verdict. The Court rejected a rule that a second trial is always prohibited in such circumstances.

Such a rule would create an insuperable obstacle to the administration of justice in many cases in which there is no semblance of the type of oppressive practice at which the double-jeopardy prohibition is aimed. There may be unforseeable circumstances that arise during a trial making its completion impossible, such as the failure of a jury to agree on a verdict. In such event the purpose of law to protect society from those guilty of crimes frequently would be frustrated by denying courts power to put the defendant to trial again. ... What has been said is enough to show that a defendant's valued right to have his trial completed by a particular tribunal must in some instances be subordinated to the public's interest in fair trials designed to end in just judgments. ${ }^{23}$

In a discussion of the problem of the Wade case, the First Gircuit has commented, citing Mr. Justice Frankfurter's dissent in Green, that "These cases seem to recognize that the defendant has in fact been subjected, at least in part, to the very type of continuing harassment which the amendment is designed to prevent, but that the exigencies of public justice

20355 U.S. 184 (1957).

21 Id. at 218-19.

22336 U.S. 684 (1949).

23 Id. at 688-89. 
outweigh the defendant's disadvantage in the particular case."24 The burdens on the defendant which the amendment was designed to prevent must be balanced against the public interest in protecting society from those guilty of crimes. When this balancing concept is applied to the problem of a new trial after appellate reversal, the practice of permitting new trials where the reversal was due to error can be justified. But a new trial after a reversal for insufficient evidence cannot be justified. ${ }^{25}$

Underlying the idea that the objective of protecting society from those guilty of crime would be substantially frustrated by releasing those defendants whose convictions have been reversed for error is the belief that errors which courts hold to be reversible may have little or no relation to the issue of guilt or innocence. When a jury weighs the evidence and concludes that a defendant is guilty, the prosecution has probably met its burden of proof even if reversible errors marred the trial. At least there is such a good chance that the defendant is guilty that to release him without a new trial would substantially impair the efficiency of the criminal law. The definition of reversible error provides support for this thesis. A conviction must be reversed if an appellate court feels that an error has had substantial influence upon the jury or if one cannot say, with fair assurance, that the judgment was not substantially swayed by the error. ${ }^{26}$ Moreover, an error may be reversible error even if there is enough other evidence, properly admitted, to sustain a conviction. ${ }^{27}$ Under such a standard it seems quite likely that many convictions are reversed even though the prosecution has satisfied its burden of proof and even though the absence of the error would not have changed the verdict of the jury.

If the possibility of a new trial after reversal for error were constitutionally barred there would be serious and detrimental consequences from either of two courses appellate courts might follow. Criminals would escape punishment if errors that now are cause for reversal became cause for acquittal since reversible error may often have little relation to innocence. On the other hand, the hazards to criminal justice would be great if courts adopted more restrictive standards of reversible error to avoid acquitting the guilty. Then the danger would be that in cases where the error might have affected the outcome of the trial, the defendant would still be imprisoned.28 In view of the difficulties for appellate

24 Killilea v. United States, 287 F.2d 212, 214 (1st Cir. 1961).

25 In Rucker v. United States, 288 F.2d 146 (D.C. Cir. 1961), the court purportedly applied this test and permitted a new trial where the evidence in the first had been insufficient. Analysis of the test would appear to demonstrate that the court was wrong.

26 Kotteakos v. United States, 328 U.S. 750, 764-65 (1946).

27 Id. at 767.

28 See Ruckle v. State, 230 Md. 580,187 A.2d 836 (1963), where a court found it had no choice but to affirm the conviction of a defendant who had refused a new trial. 
court supervision of trial court procedures which would be created by a prohibition of a new trial after a reversal for error, it does not seem unreasonable to require a defendant in such a situation to submit to a new trial.

In contrast, the considerations which justify a new trial after a reversal for error are lacking where the reversal is for lack of evidence. Instead of a presumption that the burden of proof of the prosecution has probably been met, the appellate court is specifically holding that the burden has not been met. Society should have no more fear of releasing such a defendant than of releasing a defendant who has been acquitted by a jury, perhaps even less since a jury acquittal may be based on error or on an improper weighing of the evidence. Yet in the federal system and in most states, no appeal is allowed the state after an acquittal. ${ }^{29}$

Furthermore, there is no reason to fear that an appellate court judge, deprived of the new trial alternative, would affirm a conviction where he now would reverse and grant a new trial for insufficient evidence. In the federal courts it is not enough for a judge to feel that on his reading of the record he would have voted for acquittal. "It is not for [a reviewing court] ... to weigh the evidence or to determine the credibility of witnesses. The verdict of a jury must be sustained if there is substantial evidence, taking the view most favorable to the Government, to support it." 30 Thus where a judge now would be willing to reverse, he should have no objection to acquitting. He certainly should not prefer the conviction of a defendant where he not only would vote for acquittal himself but also thinks that there is no substantial evidence to support the trial court conviction.

The distinction between reversal for error and reversal for insufficient evidence will not, of course, present itself as a perfect dichotomy in every case. The trial court may have erroneously excluded prosecution evidence which would have been sufficient to support the conviction.

29 Kepner v. United States, 195 U.S. 100 (1904). In a recent case the Supreme Court rejected the contention of a circuit court of appeals judge that the social interest in justice might outweigh the burden on a defendant caused by a state appeal of an acquittal where egregious error could be demonstrated. See Fong Foo v. United States, 369 U.S. I41 (1962), rejecting the contentions of Judge Aldrich's concurring opinion and reversing In re United States, 286 F.2d 556, 567-68 (1st Cir. 1961). Three states, Connecticut, Vermont and Wisconsin, sanction state appeals after an acquittal. State v. Lee, 65 Conn. 265, 30 Atl. 1110 (1894); VT. Stat. tit. 13, ch. 201, \&6557 (1958); State v. Felch, 92 Vt. 477,105 Atl. 23 (1918); Wrs. STAT. ANN. \$ 958.12(1)(d) (1958); State v. Witte, 243 Wis. 423,10 N.W.2d 117 (1943). Even in these states an argument can be made for forbidding a new trial after reversal of a conviction for insufficient evidence. The burden imposed on society by releasing those who have been acquitted at trial is greater than the burden imposed on society by releasing defendants whose convictions have been reversed for insufficient evidence, if one accepts what seems to be a pervasive assumption of the system-that appellate courts err less frequently than trial courts.

30 Glasser v. United States, 315 U.S. 60, 80 (1942). 
Or the appellate court may find that after erroneously admitted evidence is struck from the record there is insufficient evidence remaining to support the conviction. In both cases the considerations which permit a new trial after reversal for error should control over the considerations which should prohibit a new trial after reversal for insufficient evidence. Where the trial court erroneously excluded the state's evidence, the prosecution was kept from proving its case only by the trial court's error. Permitting a new trial in that situation would have the added advantage of giving the appellate court some opportunity to rule on errors favorable to the government. Where the appellate court holds admission of evidence error, leaving insufficient evidence in the record to support the conviction, it would be difficult to determine what other evidence the prosecution might have presented had it not succeeded in getting in the evidence which the appellate court considers inadmissible.

No undue burden is imposed on society by releasing those defendants whose convictions have been reversed for lack of evidence. The oppression and harassment which the double jeopardy clause was designed to prevent is clearly present in a new trial following a reversal for insufficient evidence. For in the insufficient evidence case an appellate court is in essence saying, "Well, the prosecution did not prove you guilty this time but they can have another chance." Although it would not be necessary for the Supreme Court to raise the distinction between reversal for error and reversal for insufficient evidence to the stature of a constitutional principle-invocation of the Court's supervisory power might be considered more appropriate-the Court should explicitly recognize that the same considerations which prohibit a new trial where an accused has been acquitted at trial apply with equal force following an appellate reversal for insufficient evidence. ${ }^{31}$

31 A number of states have explicitly considered the constitutionality of a new trial after a reversal for insufficient evidence and all have found it constitutional. People v. Hardisson, 61 Cal. 378 (1882); People v. Benson, 24 Ill. 2d 159, 180 N.E.2d 483 (1962); State v. Bowman, 94 Iowa 228, 62 N.W. 729 (1895); State v. Phillips, 175 Kan. 50, 259 P.2d 185 (1953); Harris v. State, 158 Miss. 439, 130 So. 698 (1930); State v. Patton, 308 S.W.2d 641 (Mo. Sup. Ct. 1958); State v. Lamoreaux, 20 N.J. Super. 65, 89 A.2d 469 (1952); State v. Robinson, 100 Ohio App. 466, 137 N.E.2d 141 (1956); Cross v. Commonwealth, 195 Va. 62, 77 S.E.2d 447 (1953); Montgomery v. State, 136 Wis. 119, 116 N.W. 876 (1908). In New Mexico the state supreme court held, citing Sapir, that "the effect of a reversal for lack of sufficient evidence to support a conviction is not different from an acquittal by the jury and requires that the defendant be discharged." State v. Moreno, 69 N.M. 113, 115, 364 P.2d 594, 595 (1961). Other states have not explicitly decided the question, but language in cases and statutes dealing generally with the problem of a new trial after appellate reversal suggests that most states would follow Bryan. 